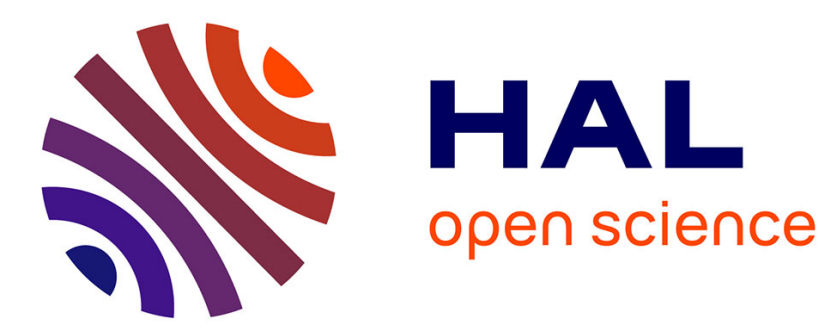

\title{
Positron irradiation effects on polypropylene
}

\author{
T. Suzuki, T. Miura, Y. Oki, M. Numajiri, K. Kondo, Y. Ito
}

\section{To cite this version:}

T. Suzuki, T. Miura, Y. Oki, M. Numajiri, K. Kondo, et al.. Positron irradiation effects on polypropylene. Journal de Physique IV Proceedings, 1993, 03 (C4), pp.C4-283-C4-285. 10.1051/jp4:1993445 . jpa-00251488

\section{HAL Id: jpa-00251488 https://hal.science/jpa-00251488}

Submitted on 1 Jan 1993

HAL is a multi-disciplinary open access archive for the deposit and dissemination of scientific research documents, whether they are published or not. The documents may come from teaching and research institutions in France or abroad, or from public or private research centers.
L'archive ouverte pluridisciplinaire HAL, est destinée au dépôt et à la diffusion de documents scientifiques de niveau recherche, publiés ou non, émanant des établissements d'enseignement et de recherche français ou étrangers, des laboratoires publics ou privés. 


\title{
Positron irradiation effects on polypropylene
}

\author{
T. SUZUKI, T. MIURA, Y. OKI, M. NUMAJIRI, K. KONDO and Y. ITO*
}

National Laboratory for High Energy Physics, Radiation Control Center, Oho, Tsukuba, Ibaraki 305, Japan

"Research Center for Nuclear Science and Technology, The University of Tokyo, Tokai, Ibaraki 319-11, Japan

\begin{abstract}
Positron irradiation effects on polypropylene (PP) and polyethylene during the positron 1 ifetime measurements have been studied in detail. The effect, which was to decrease $I_{3}$, has been found to be 1 arger in air than in vacuum. For PP, when the 1 ifetime measurements were performed at temperatures above $348 \mathrm{~K}$, the radiation effect was scarcely observable. However at low temperature the radiation effect was accumulated and $I_{3}$ was decreased during the measurements. Irradiation of co-60 $\gamma$-ray up to the dose of 300 MRad also lead to similar decrease in $I_{3}$, but the decrease due to $\gamma$-irradiation was not as large as that due to the positron irradiation. Irradiation effect of positrons appears to be different from that of $\gamma$-rays.
\end{abstract}

1. Introduction

PA is a useful technique to investigate characteristics of materials. However, as reported by walender et al. $/ 1 /$, PA must be carefully applied to study polymers. As positron irradiation induces radiation damage to polymers during the measurement of $\mathrm{PA}$, intensities $\left(\mathrm{I}_{3}\right)$ of long-lived components of o-Ps decrease gradually with the measurement time. They showed that the decrease depends on the kind of polymers. Large decrease was observed for polypropylene (PP), and it was attributed to radicals formed by the positron irradiation. However, it seems that the decrease in $\mathrm{I}_{3}$ is not simply explained by radicals and there are several factors contributing to it $/ 2,3,4 /$.

\section{Experimentà}

The PA experiments were conducted with a conventional fast-fast coincidence system having a time resolution of 270 ps full width at half 
maximum (FWHM). The positron source was prepared by depositing ca. 1 $\mathrm{MBq}(30 \mu \mathrm{Ci})$ of aqueous ${ }^{22} \mathrm{NaCl}$ on a Kapton foil of $7 \mu \mathrm{m}$ thickness and $10 \times 10 \mathrm{~mm}$ area. The diameter of the spot of ${ }^{22} \mathrm{Na}$ source was ca. 2 $\mathrm{mm}$ and the dose rate was estimated to be $0.1 \mathrm{Mrad} / \mathrm{h}$ at most.

3. Results and discussion

3. 1 Irradiation effect on PP and HDPE in air and vacuum

Irradiation effects of positrons on PP and high density polyethylenes (HDPE) were investigated in vacuum and air at $303 \mathrm{~K}$. Intensities of the o-Ps $\left(\mathrm{I}_{3}\right)$ decreases with elapsed time and the decrease in $\mathrm{I}_{3}$ $\left(\Delta \mathrm{I}_{3}\right)$ can be summarized as follows:

$$
\begin{array}{cccc}
\Delta I_{3} \text { in } 60 \mathrm{~h} \text { (Vacuo) } & -5.7 \% & \text { HDPE } \\
\Delta \mathrm{I}_{3} \text { in } 60 \mathrm{~h} \text { ( } \mathrm{Air} \text { ) } & -7.8 \% & -3.8 \%
\end{array}
$$

The decreases in $\mathrm{I}_{3}$ of PP and HDPE is consistent with the previous results, and $\Delta \mathrm{I}_{3}$ in air is larger than that in vacuum. The difference between the experiments in air and vacuum is considered to be due to the radiation induced oxidation, which produces $>C=0$ groups in polymers irradiated in air. The carbonyl groups with its large electron affinity may reduce Ps formation in polymers.

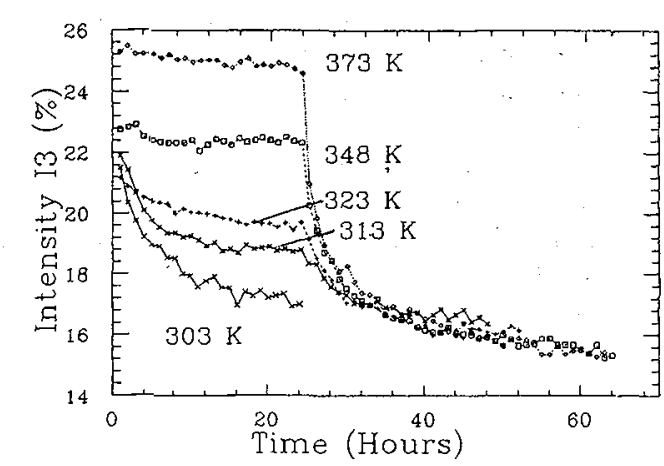

Figure 1 ,

$I_{3}$ vs elapsed time at 5 different temperatures. Samples were kept for

$24 \mathrm{~h}$ at these temperatures in vacuum and then cooled to $303 \mathrm{~K}$.

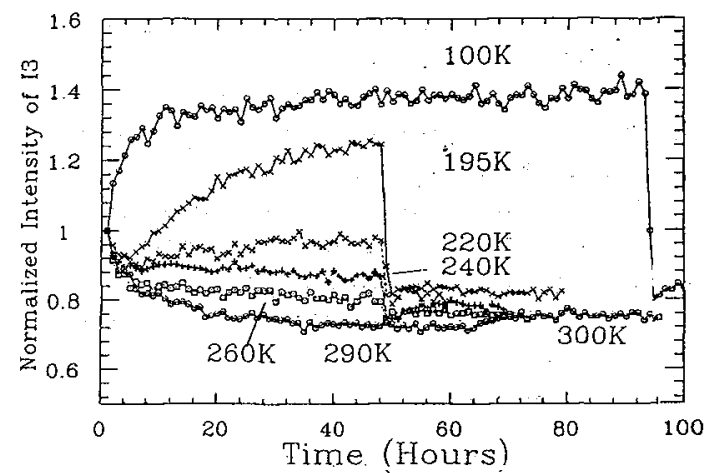

Figure 2,

$I_{3}$ vs time at low temperatures

\subsection{The influence at high temperature (Fig. 1)}

Above $348 \mathrm{~K}, \mathrm{I}_{3}$ was constant and, as soon as the temperature was restored to $303 \mathrm{~K}$, it decreased in the same way as for the unirradiated samples, which indicates irradiation effect is not accumulated at high temperature.

3.3. The influence at low temperature (Fig.2 and Fig.3)

Figure 2 shows $I_{3}$ vs time for 6 different temperatures: for four 
temperature cases $(260 \mathrm{~K}, 240 \mathrm{~K}, 220 \mathrm{~K}$, and $195 \mathrm{~K})$, the sample temperatures were restored to $303 \mathrm{~K}$ after $48 \mathrm{~h}$ and for $100 \mathrm{~K}$ after $93 \mathrm{~h}$. These results indicate that, as soon as the temperatures are restored to $303 \mathrm{~K}, \mathrm{I}_{3}$ becomes the same value as that of samples irradiated for the same length of time at $303 \mathrm{~K}$. At $100 \mathrm{~K}$ simply $\mathrm{I}_{3}$ increases, whereas above $100 \mathrm{~K} \mathrm{I}_{3}$ decreases first and then starts to increase. The turning point for increase and the amount of the increase depend on the temperatures. At 100K, the increase in $\mathrm{I}_{3}$ may be explained by the termination of molecular motion/5/, which takes many hours. Also radicals are frozen and hence cross-linkings are suppressed. The crosslinkings occurs at room temperature and $\mathrm{I}_{3}$ of these samples increase slowly at $100 \mathrm{~K}$. The slow increase is related to relaxation and can be fitted with the so-called voigt model. Figure 3 shows the fittings.

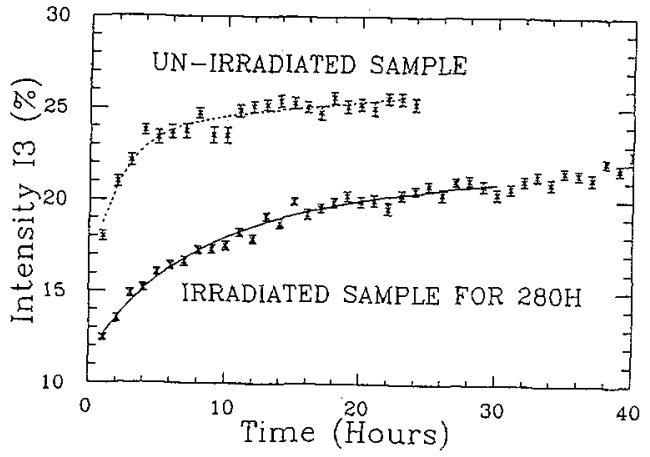

Figure 3 ,

$e^{+}$irradiation time effect

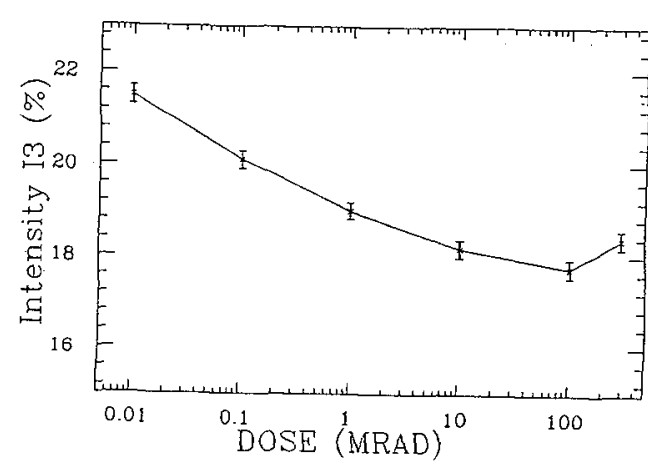

Figure 4 ,

$y$-irradiation effect on PP

3.4 Comparison with $\gamma$-irradiation (Fig.4)

For $\gamma$-irradiated samples the data were collected within $1 \mathrm{~h}$ from the start of measurements. For 100 MRad irradiation of $\gamma$-rays, the decrease in $\mathrm{I}_{3}$ was about $3.7 \%$ from that of unirradiated samples. However the decrease in $\mathrm{I}_{3}$ for samples irradiated by positron source is about $5.7 \%$ after $60 \mathrm{~h}$ : the dose by the positron irradiation can be estimated to be at most 0.06MRad. This result suggests that the positron irradiation gives larger radiation effect on PP than the $\gamma-$ irradiation effect.

References

/1/ M.Walender and F.H.J. Maurer, Mat.Sci.Forum 105-110('92)1811

/2/ Y.C.Jean and H.J.Ache,J.Phys.Chem., 82,656(1978)

/3/ G.H.Wang,M.K.Teng, D.X.Shen, C.Y.Yi, Y.Y.Zhou, Y.Y.LU, H.W.Wang, Y.Z.Zhu, and L.Dou, Phys.Stat.Sol.(a)106(1988)K1

/4/ T. Suzuki, Y.Oki, M.Numajiri, T. Miura, K.Kondo and Y. Ito J.Polym.Sci., 30 ('92) 517

/5/ P.Kindl and G.Reiter, phys.stat.sol.(a) 104('87)707 